UDC 005.3:379.84-056.26

DOI https://doi.org/10.26661/hst-2021-9-86-09

\title{
MANAGEME OF RECREATIONAL ACTIVITIES FOR PERSONS WITH PHYSICAL DISABILITIES
}

\author{
(C) SVAGZDIENE, BIRUTA \\ Lithuanian Sports University (Kaunas, Lithuania) \\ e-mail: biruta.svagzdiene@1su.lt \\ ORCID iD: http://orcid.org/ 0000-0001-6016-6019 \\ Литовский Університет Спорту, 6, Каунаський повіт, 44221 Каунас, Литва \\ Lithuanian Sports University, 6, str. Sporto, Kaunas municipality, 44221 Kaunas, Lithuania \\ (C) GRANTS, JURIS \\ Latvian Academy of Sport Education (Riga, Latvia) \\ e-mail: juris.grants@1spa.lv \\ ORCID iD: http://orcid.org/: 0000-0003-3116-9119 \\ Latvian Academy of Sport Education Brivibas street 333, Riga, Latvia \\ (C) GUTIENE, VIRGINIJA \\ Kaunas college/ University of Applied Sciences (Kaunas, Lithuania) \\ e-mail: virginija.gutiene@go.kauko.lt \\ ORCID iD: http://orcid.org/ 0000-0001-9402-5767 \\ Литовский Університет Спорту, 6, Каунаський повіт, 44221 Каунас, Литва \\ Lithuanian Sports University, 6, str. Sporto, Kaunas municipality, 44221 Kaunas, Lithuania
}

\begin{abstract}
A balance between activity and rest is essential for human health. Recreation is especially relevant for the disabled, who want to regain their physical, spiritual and emotional strength, and at the same time spend their free time meaningfully. Recreation improves not only physical capacity, motor skills, but also the self-esteem of the disabled, the ability to communicate and cooperate, promotes motivation to participate in various activities. People with disabilities still face a lack of information about recreational activities and their accessibility, which may be related to a lack of motivation to participate in physical activities and low levels of physical activity. The relevance of the research is also determined by the lack of research related to the management of recreation and leisure of the disabled in Lithuania. Those who want to solve the problems of the quality of leisure time in the social system today especially lack qualified knowledge and research. It is expected that the research of this work will at least partially reveal whether the recreation and leisure of the disabled in Lithuania is sufficiently well organized and accessible to persons with physical disabilities. The situation in Lithuania in terms of recreation for the disabled has not been sufficiently studied, therefore this work will help to assess the current situation and provide guidelines for the further development of recreation for the disabled. Objective: To evaluate the usefulness of recreational activities for people with physical disabilities, the possibilities of their organization and implementation. Tasks: to define the accessibility and organization of health promotion in recreational activities for persons with physical disabilities; to reveal the possible influence of economic-financial, informational, physical and psychosocial environmental factors on the participation of the disabled in recreational activities for the purposes of health promotion; to discuss the leisure needs and possibilities of satisfaction of persons with mobility impairments. Methods: analysis, systematization and interpretation of scientific literature.
\end{abstract}

Keywords: management of recreational, health, physical disability, recreational activities, leisure

A balance between activity and rest is essential for human health. Recreation is especially relevant for the disabled, who want to regain their physical, spiritual and emotional strength, and at the same time spend their free time meaningfully. Recreation improves not only physical capacity, motor skills, but also the selfesteem of the disabled, the ability to communicate and cooperate, promotes motivation to participate in various activities. People with disabilities still face a lack of information about recreational activities and their accessibility, which may be related to a lack of motivation to participate in physical activities and low levels of physical activity.

The relevance of the research is also determined by the lack of research related to the management of recreation and leisure of the disabled in Lithuania. Those who want to solve the problems of the quality of leisure time in the social system today especially lack 
qualified knowledge and research. It is expected that the research of this work will at least partially reveal whether the recreation and leisure of the disabled in Lithuania is sufficiently well organized and accessible to persons with physical disabilities. The situation in Lithuania in terms of recreation for the disabled has not been sufficiently studied, therefore this work will help to assess the current situation and provide guidelines for the further development of recreation for the disabled.

Objective: To evaluate the usefulness of recreational activities for people with physical disabilities, the possibilities of their organization and implementation.

\section{Tasks:}

1. To define the accessibility and organization of health promotion in recreational activities for persons with physical disabilities.

2. To reveal the possible influence of economic financial, informational, physical and psychosocial environmental factors on the participation of the disabled in recreational activities for the purposes of health promotion.

3. To discuss the leisure needs and possibilities of satisfaction of persons with mobility impairments

Methods: analysis, systematization and interpretation of scientific literature.

\section{The concept of health and its links to physical} disability
Social welfare means the conformity of the way of life of a member of society, the distribution of income and other aspects of its life with the common values of the members of that society. That well-being is high when people's desires and behaviors are in line with the values of their society [1]. In everyday life, the concept of health can be understood very differently. Health is a broad concept that can embody a wide range of meanings, from narrowly technical to all-encompassing moral or philosophical meanings [2].

At present, most national health interventions are aimed at treating diseases and only a few at improving health quality in general [3]. Therefore, health needs to be pursued by creating a healthy environment, strengthening community activities, developing personal skills and reorienting health services and their accessibility not only for the disabled but also for the disabled (fig. 1) [4].

Activity - a set of actions with the help of which a person establishes himself in the world:

1. Human nature determines the need of each individual to act and change at the same time

2. Link human development and activity

3. Through activities, a person influences his health

4. A balance between activity and rest is essential for human health

5. Activities must be meaningful. It is given meaning by the patient's attitude towards the activity

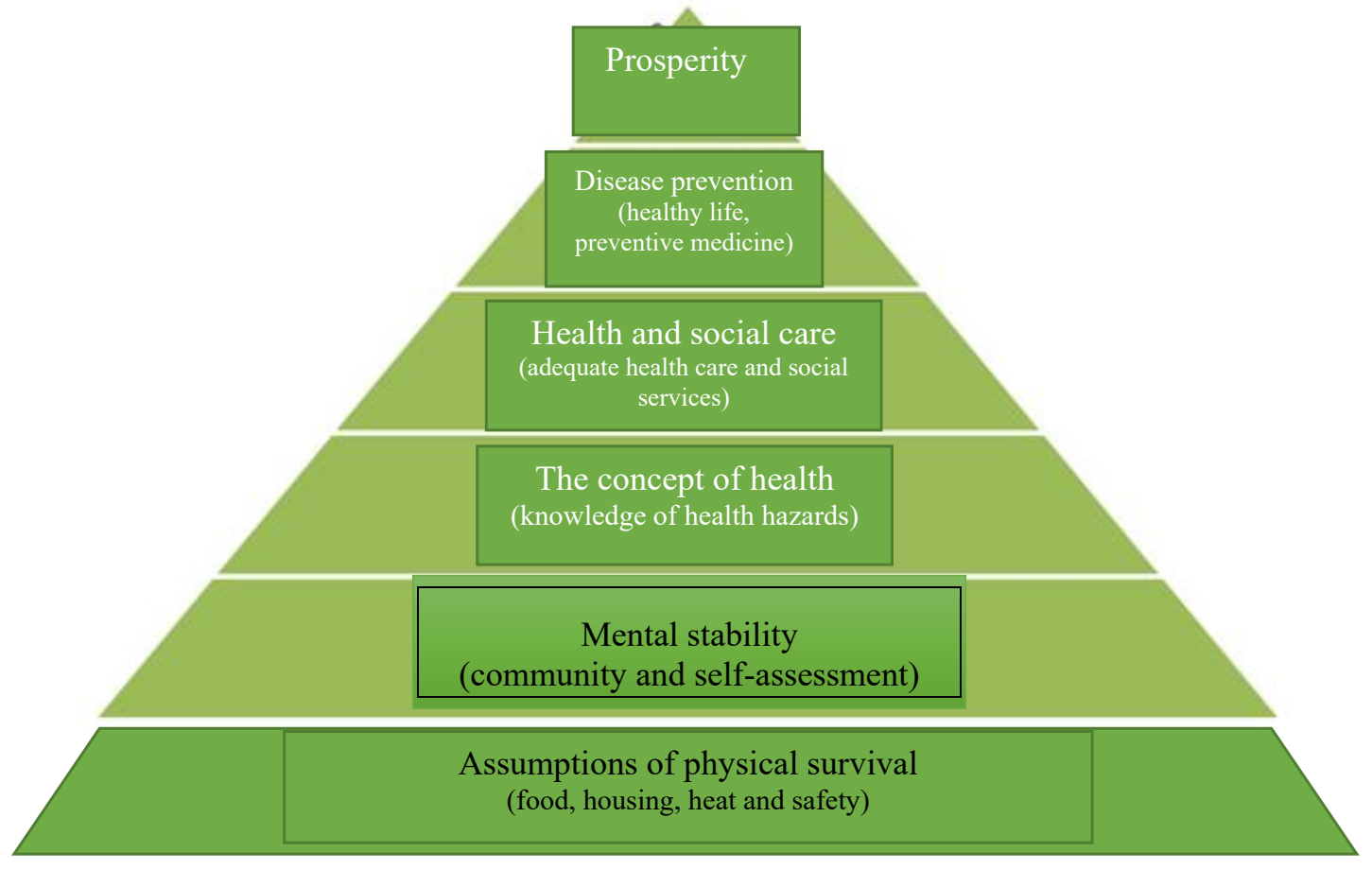

Fig. 1 Health triangle 
6. The realization of human activity is determined by the world around it

7. Human existence is a social process. It is understood as a constant interaction with other individuals

Organization of recreational activities and accessibility for the disabled

Organizations engaged in recreational activities are non-commercial entities, i. y. producers or developers of a non-commercial product, they are interested in non-commercial sale, i. y. providing recreational activities for the disabled. The Lithuanian non-commercial sector is underdeveloped due to a lack of funds and organizational capacity. In addition, it confronts the dual feelings of both government and society [5].

An organization is a social entity created for a specific activity; it is a goal-oriented, deliberately structured system with relatively defined boundaries of its activity. A small organization often manages limited resources, including human resources. For this reason, employees in an organization need to be flexible and able to perform many different tasks and functions. The organization has the following characteristics [6]:

1) social group - people working in an organized way;

2) purposeful activities - services provided and income distributed;

3) open to the environment - maintains relations with other organizations and institutions;

4) has a management structure divided into responsibilities; control and coordination mechanisms are in place;

5) activities are regulated by legal acts.

Public recreation institutions, regardless of their ownership, use the resources available to the country land, landscape, labor, capital, buildings, facilities to the final product of the country - recreation services [7].

Recreation for the disabled. Recreatio for the disabled - recovery of strength, health, joy of life, meaning and enjoyment of life. It is an activity that «liberates» a person from his various social roles and promotes a person's creativity. Recreation components:

First. Biological-a person plans activities, works, creates in order to achieve social equality, freedom of personality, spiritual development. It is a process of existence, of human becoming;

Second. Physiological - vital functions of the human body, health, ability to work, longevity

Third. Psychological - a person's mental condition directly affects health and ability to work;
Fourth. Social - a person's social status is important;

Fifth. Emotional - a person's direct experience of feeling, the spiritual state is related to the surrounding environment;

Sixth. Cultural-spiritual - the totality of material and spiritual values of a person (depending on age, education, profession, etc.).

The term «leisure» is used to refer to time and «recreation» to activity. It can have active and passive forms.

It is often difficult for people with disabilities to express their preferences because they cannot imagine or know the activities they can choose from due to physical or intellectual problems.

Properly organized recreational activities are a particularly effective means of social integration of people with disabilities.

Inability to use one's free time rationally, a poor life is the cause of many social problems (alcoholism, drug addiction, crime, suicide). Problematic forms of leisure are computer games, watching TV, etc., because they are associated with high mental stress.

Applied physical activity. These are adapted activities, facilities, environments, facilities, biosocial or psychopedagogical programs for people with physical, sensory, psychological, age and social disabilities and special needs.

Disabled sports - the application of sports or its elements for the recreational purposes of the disabled. Cultivating a sport for the disabled to achieve competitive results.

Theoretical models of the disabled: Individual model; The social model [8].

It should be noted that in the field of product and service development insufficient account is taken of the needs of people with disabilities. Many goods and services, like much of the physical infrastructure, remain inaccessible to people with disabilities [9]. Communication from the European Commission «2010-2020 European Disability Strategy. Continuing to build a barrier-free Europe «defines accessibility as the ability of people with disabilities to use physical infrastructure, transport, information and communication technologies (ICT) and other facilities and services on an equal basis with others, as there are still serious barriers in all these areas [9].

The health of the population is the greatest social and economic value of society. It is not just the absence of disease and physical defects, it is the physical, spiritual and social well-being of people. The potential of health and the conditions for maintaining it are 
determined by the stability of the economic system, guarantees of social security and education of the society, accessible and appropriate health care, quality of work, living and natural environment, efforts of the population to promote health. Good public health is one of the most important preconditions for national security and prosperity [10].

\section{Environmental factors of participation of the disabled in recreational activities}

The impact of environmental factors on individuals with health changes is very diverse and complex. These environmental factors are: economic financial, informational, physical and psychosocial.

Impact of economic - financial environment. People with physical disabilities are people with special needs that require considerable resources to meet: health care, special equipment for the disabled, basic necessities, adaptation of the living environment, recreation and leisure. Consumption and the satisfaction of various needs are directly related to income. Everyone feels happy when their needs are fully met. Unfortunately, people with disabilities do not always have access to the services and goods necessary to develop their abilities and ensure a decent standard of living [11].

Impact of the information environment. In the last decade, the main focus has been on informing the public about the problems of the disabled, but the information environment has not been sufficiently adapted for the disabled themselves. People with disabilities feel excluded from the use of information and communication technologies [12]. Due to the lack of a well-adapted environment, they do not have access to successful sources of information, although the information environment is currently improving: non-governmental organizations provide compensatory equipment to facilitate access to information, training in the use of computer equipment, and so on. [12].

Effects of the physical environment. Most sports equipment manufacturers do not produce suitable equipment for the disabled, so many people with disabilities give up physical activity. Sports or health clubs do not purchase equipment for the disabled because of its high cost or the fact that only a small proportion of people with disabilities will be able to use it. Also, if equipment is purchased for the disabled, it is usually only for one or two exercises. People with disabilities are dissatisfied, especially when disabled people who play nearby have access to a much wider range of facilities. They feel ignored, and their recreational programs are fairly uniform [13; 14].
Impact of psychosocial environment. After becoming disabled, many individuals experience depression, lose confidence, and feel that their lives are limited. One of the ways to overcome negative thoughts is through sports. It has long been known that sport is entertainment, recreation, an opportunity to improve and develop new skills. Such achievements help to communicate and cooperate, join recreational programs, improve their physical condition. This is the path to comprehensive improvement [15]. People with disabilities are looking for appropriate activities that will help them gain a satisfactory physical condition and, in doing so, help reduce or even prevent dangerous diseases such as heart disease. In addition, physical activity has a positive effect on the psychological state of the disabled. Physically active people are less likely to suffer from depression or anxiety. People with disabilities express their «I» in recreational activities, which leads to self-expression, independent lifestyle, favorite activities and work, participation in public life. In this way, they become full members of society [16]. One of the prerequisites for reducing the emotional and psychological stress of people with disabilities is the creation of a friendly environment for them. In addition, professionals to work with people with disabilities must be properly selected and trained. Friendship and compassion are a prerequisite for them, and professionalism is clear, as people with various disabilities need to be able to choose the right activities [17; 18].

An analysis of the literature influencing the decision of disabled people to visit a sports / recreation center/ club revealed that press advertising, broadcast on $\mathrm{TV} /$ radio and advertising posters or billboards are an ineffective means of encouraging disabled people to participate in physical activity.

The economic-financial and physical environment is a very important aspect for a person with a physical disability, which provides an opportunity to engage in sports / recreational activities or hinders such activities. «Financial motives» (eg excessive service prices) are not a determining factor in the ability to engage in physical activity.

Analyzing the adaptability of the environment, it was observed that the environment not adapted for the disabled is not a significant barrier to participation in physical activity. This means that the participation or non-participation of people with disabilities in physical activity is determined not by the external environment but by the internal attitude.

Significant interference restricting sports / recreational activities. Every sporting activity 
is important for the human body. It is especially important for a disabled person to move, develop their body and improve their independent living skills. The disabled are provided with satisfactory conditions to spend recreational leisure time, the disabled are provided with good leisure and recreational conditions in Lithuania.

People with disabilities usually face the following barriers: access to health care, education, employment, transport, information, and so on. The WHO, which brings together 193 countries, has proposed the introduction of a biopsychosocial model of health care, which assesses not only the causes of health problems but also the consequences of diseases, injuries and birth defects, which can be reduced by adapting the environment, technical rehabilitation measures and influencing patient behavior. To this end, the WHO The International Classification of Functioning, Disability and Health has been published $[19 ; 20]$.

Staševičienè \& Fatkulina [21] performed an examination of the suitability of architectural solutions for the disabled in 83 companies of different purposes in Lithuania, where the elements of the F1-F9 physical environment were assessed. A total of 57 items were rated in these companies. The results showed that the overall eligibility is only 19 percent (table 1). In detailing the results of the study, it can be mentioned that the physical adaptation of the building and the integrity of this adaptation are extremely important for people with reduced mobility, as well as for the blind and partially sighted. It is taken into account that if the path leading to the building is adapted, the entrance to the building is adapted, other elements of the building must be adapted: access to specialists, elevators, toilets, emergency exit, etc. Users of the user group pointed out that the principles of universal design are often ignored - a custom entrance, but it is difficult to navigate and find the required service inside the building. The members of the group of service providers and product manufacturers believe that people with reduced mobility can enter the institution and find the offices, toilets and emergency exits they need on their own (if the building is adapted for people with reduced mobility).

In the case of other disabilities, such as those with visual or hearing impairments, other ways are sought, such as offering an employee who can help the disabled person.

According to service users with various functional possibilities, one of the most important criteria for the availability of services is access to the building. However, access is often hampered by completely inadequate or poor-quality infrastructure - too steep ramps, lack of railings, too narrow lifts, and so on. Participants in the focus group of service providers and product manufacturers indicated that they often lack knowledge about the adaptation of the environment for people with disabilities, so that adaptation for people with disabilities is often intuitive. In cases where providers consider that accessibility for people with disabilities is not necessary because of the high investment involved, clients are served at their home or meetings are arranged in places for the disabled.

An analysis of the issue of environmental adaptation for the visually impaired showed that tactile walking indicators facilitate the movement of the blind in the city. However, in the opinion of users with visual impairments, tactile walking indicators cannot be relied on yet because their distribution is uneven, there are various unmarked and indistinguishable obstacles: poles, trash cans, advertising stands, etc. This arrangement of tactile

Table 1

Results of the verification of the availability of services and product suitability of architectural solutions [21]

\begin{tabular}{|l|c|c|c|c|c|c|c|c|c|c|}
\hline \multicolumn{10}{|c|}{ VERIFICATION SHEETS RECEIVED } \\
\begin{tabular}{|c|c|c|c|c|c|c|c|c|c|c|}
\hline \multicolumn{1}{|c|}{$\begin{array}{c}\text { Overall } \\
\text { eligibility (\%) }\end{array}$} \\
\hline F1 & F2 & F3 & F4 & F5 & F6 & F7 & F8 & F9 & viso & \\
\hline \multicolumn{10}{|c|}{ overall suitability of all completed sheets (\%) } \\
\hline 47 & 55 & 67 & 47 & 41 & 59 & 36 & 43 & 21 & 57 & 19 \\
\hline
\end{tabular}
\end{tabular}

\begin{tabular}{|l|l|c|l|}
\hline F1 & Car parking & F6 & Doors, windows \\
\hline F2 & Paths to the building, ramps & F7 & Toilets and toilets \\
\hline F3 & Entrance to the building & F8 & Customer service locations \\
\hline F4 & Corridors & F9 & Interior details \\
\hline F5 & Stairs, elevators & Viso & \\
\hline
\end{tabular}


walking indicators sometimes puts blind pedestrians at risk of injury and / or loss. Visually impaired users emphasize that if tactile walking indicators were evenly distributed in the city and obstacles were marked and / or fenced, it would be a great help for the blind to move independently in the city.

\section{Leisure needs and opportunities for people with reduced mobility}

Participation in leisure activities develops the communication, self-esteem and confidence of people with mobility impairments in social situations. For people with reduced mobility, communication is one of the most important factors that can activate social inclusion and eliminate the external and internal stigma of disability.

Accessibility of recreational activities for persons with physical disabilities, environment and utility. One of the tasks of applied physical science and practice is to theoretically substantiate and apply appropriate methods and tools to promote the independence of persons with disabilities, which according to the theory of personal self-determination can be achieved only by developing internal control and responsibility for one's actions. Therefore, these theoretical provisions must be used as a basis for the development of programs for the organization of leisure time, physical education, sports for the disabled and their physical rehabilitation of the disabled, strictly regulating the external assistance of specialists and others [22]. An analysis of the scientific literature has shown that physical activity improves the functional capacity or physical capacity and health of people with disabilities. The impact of increased physical activity on the health and wellbeing of people with disabilities can be much greater than that of the healthy. Although there is little improvement in endurance, strength and flexibility can greatly improve the quality of life of a person with a disability. Regular physical activity, sports, and active recreation are known to reduce mortality from a variety of causes, although studies of current physical activity patterns in Western countries show that this alone is not enough to improve health [23]. Indeed, people with disabilities are much more likely to experience lower levels of physical activity, but the beneficial effects of physical activity on both disabled and non-disabled people are evident [23]. According to J. Mikelkevičiüte [24], the participation of the disabled in physical activity and exercise is associated with improved physical capacity and psychological benefits. The work of many scientists, which examines the problems of the influence of physical culture on the development of personality, highlights the aspects of the positivity of sports activities in the organization of leisure time.

Summarizing the thoughts of foreign and Lithuanian authors, it is possible to doubt that the organization of leisure time interacts with the advantages provided by physical activity. People with disabilities who exercise are more confident in their abilities, their physical performance, biosocial skills, psychosocial health and, with them, their overall quality of life are improving. As one of the main barriers to engaging in applied physical activity, the authors cite an inappropriate environment. Thus, we can say again that the adaptation of the environment will also improve the quality of life of people with disabilities [25].

Leisure needs of persons with reduced mobility. As noted by L. Alčiauskaite and L. Šinkariova [26], physical disability and severe chronic diseases cause a person many different physiological and psychological problems and challenges, such as pain, impaired physical functioning, lifestyle changes, social stigma, dependence on other persons. assistance, a threat to dignity and self-esteem. According to the authors, disability-related stressors can weaken a person's ability to maintain emotional balance and faith in a favorable future. In this case, the internal resources available to the person with a disability become very important in overcoming the problems and obstacles related to the disability [26].

In order to be socially active, the inclusion of people with disabilities is encouraged by their participation in various employment activities, as quality employment is considered a key condition for social inclusion [27]. D.E. Rohe and J.S. Research by Krause [28] shows that employment is one of the most important factors in ensuring a person's greater adaptability to disability. The employment of a person with a disability is associated with higher self-esteem, more positive emotions, lower risk of depression, and higher quality of life [29]. In addition, having employment expands the opportunities for social participation of the disabled, increases their involvement in social activities, helps to make new friends. Conversely, those who do not participate in any employment activities are more depressed, have decreased functional activity, are more rapidly aging, and have a lower sense of security [30;31].

Leisure activities are usually perceived as recreation, but at the same time the personality is given the opportunity to improve according to their needs, to discover hobbies, looking for new areas of 
interest. According to J.R. Šinkūnienè [32], the most important task of leisure time is to ensure quality time, creating conditions for the formation of the most diverse personality possible, which would be able to integrate into society, have the opportunity to regain physical and spiritual strength.

Leisure is one of the areas of socio-cultural work [23]. N. Kašètienè [33] observes that when providing socio-cultural services, individuals can communicate, participate in group social work classes, engage in favorite activities, which are organized according to need. According to D. Savickaite [34], socio-cultural activities are one of the ways to achieve positive socialization in every person's life. Both the smallest group, the family, and communities based on interests or territory facilitate the socialization processes of each of their members by using examples of imitation, persuasion, conformism, conscious follow-up, social media, and cultural mechanisms.

J.R. Šinkūnienè [32] thinks similarly, who states that socio-cultural services are provided by reducing social exclusion, activating the community, which can guide members of society, seek positive socialization and positive shifts, and shape society's values. According to A. Aleknaitè - Bieliauskienè [35], socio-cultural work is focused on both the problem and further social development, and is based on two principles - integrity and concentration of population initiatives.

D. Šèporaitytė [36], having conducted a study on the construction of work, romantic, family relationships of persons with mobility impairments, notes that participation in creative and sports activities is very important for the development of relationships. According to V. Vitkienè [37], by engaging in tourism, sports or creative artistic activities, people with disabilities participate in the recreation process, they improve their physical, psychological and emotional condition, communicate with each other, strengthen communication skills and build relationships. Research by L. Radzevičienè, L. Miliūnienè, and V. Gudonis [38] confirms that people with physical disabilities feel more satisfied with life and their mental health is assessed more favorably than those who do not do sports. I. Beneševičiūtè's [39] research confirms that persons with disabilities, by participating in activities promoting creativity, foster creativity, strengthen their identity, assuming a socially valuable role as a creator, raise selfesteem and form a positive attitude towards people with disabilities. A study by L. Jokūbpreikštas and V. Gudonis [40] on the links between psychological reactions of adults with physical disabilities to their social activity showed that social activity is more common in women with disabilities than in men with physical disabilities [40].

The Convention on the Rights of Persons with Disabilities [41] states that everyone, regardless of his or her disability, must be able to participate in various leisure activities on an equal footing with others, and the state must encourage and encourage the widest possible participation and access to such services. Therefore, they must be integrated into cultural and sports activities, have the opportunity to participate in these activities together with other members of society. However, the research conducted by L. Alčiauskaite and L. Šinkariova [42] shows that in Lithuania too little attention is paid to the resources available to people with disabilities and the opportunities to strengthen them through employment. J. Požèrienè, G. Leleika and V. Kailius [43] point out that due to lack of funds, disabled people's organizations have less opportunities to equip premises for the development of leisure activities and to employ qualified employment specialists. According to the Lithuanian Association of the Disabled, people with disabilities whose places of residence are further away from the city cannot use leisure employment services because there are no day care centers, and those living in larger cities and having the opportunity to participate in offered employment activities lack a greater variety of services [44].

\section{Conclusions and practical recommendations}

1. For people with physical disabilities, immobility means 'being within four borders', so access to health and recreational activities is very important to them.

2. The movement plays an important role in the lives of people with disabilities, as it is one of the ways to solve many physical, psychological and social problems. Organizations engaged in recreational activities are non-profit entities and therefore participate in various projects in order to obtain funding for their activities.

3. The Lithuanian non-commercial sector is underdeveloped due to a lack of funds and organizational capacity. Therefore, the planned works are planned in advance, setting priorities and taking into account financial resources. Physically disabled people are selected according to the intended purpose of the ongoing projects, namely that participation in the project would have a lasting value for the person. However, due to low funding, not everyone can get to the organized camp. 
4. After assessing the factors of the economicfinancial environment, it can be stated that recreational sports programs for the disabled are mainly financed from the state budget. However, the funds allocated from the state budget are constantly insufficient for systematic activities. Sports for the disabled have very few private sponsors because they are not as attractive or professional as sports for the disabled.

5. Everyone, regardless of his or her disability, must be able to participate in recreational, leisure and sports activities on an equal footing with others, and the state must encourage and encourage the participation of people with disabilities as much as possible and ensure access to such services. Leisure, and especially active leisure is beneficial for the disabled, it not only improves physical condition, but also emotional.

6. Leisure improves motor skills, physical capacity, can increase the amplitude of movements. It also helps to integrate more easily into society, improves social skills, increases self-worth, encourages communication, provides an opportunity to realize oneself as a person. Thus, leisure is especially important from childhood, because with its help, a multifaceted personality is formed.

7. In summary, in order to achieve the inclusion of the disabled through leisure employment services, it is necessary to pay attention to the needs and interests of the disabled, to remove obstacles to achieving the set goals, to develop social services, access to assistance for full integration of the disabled.

\section{References}

1. Jokubaitis, A., \& Norkus, Z. (2006). Socialinès gerovès koncepcijos ir pilietybès renta kaip viešosios politikos orientyrai. Sociologija. Mintis ir veiksmas, 18, 5-36.

2. Javtokas, Z. (2009). Sveikatos stiprinimo konspektas. Vilnius.

3. Vilniaus sveiko miesto biuras. (2000). Views: 10-09-2021. Internet access: www.vsmb.lt/samprata

4. Laškovaitè, S. (2012). Fizinę negalią turinčiųjų sveikatos striprinimo rekreacine veikla organizavimas. Kaunas: LSMU.

5. Rūtelionè, A. (2007). Marketingo sprendimai nekomercinèje veikloje. Kaunas: Technologija.

6. Klimavičienè, D. (2009). Laisvalaikio ir sporto klubų veikla. Kaunas: LSU.

7. Vitkienè, E. (2008). Rekreacija: rekreacijos marketingo tyrimai. 2-as leid. Klaipèda: S. Jokužio spaustuvè.

8. Davis, L. J. (2016). The disability studies reader. Routledge.

9. Komisijos Komunikatas Europos Parlamentui, Tarybai, Europos ekonomikos ir socialinių reikalų komitetui ir regionų komitetui „,2010-2020 m. Europos strategija dèl negalios. Tolesnis siekis kurti Europą be kliūčių“ / Europos komisija, Briuselis, 201011 15. Views: 30-08-2021. Internet access: http://eurlex.europa.eu/LexUriServ/LexUriServ.do? uri=CELEX:52010DC0636:LT:NOT

10. Jociutè, A. \& Valentienè, J. (2020). 18-29 metų jaunų žmonių sveikatos raštingumas Lietuvoje. Visuomenės sveikata, 3(90), 41-47.

11. Čepienè, A. \& Petkevičiūtè, S. (2019). Universalaus dizaino pritaikymo teoriniai aspektai judèjimo negalès kontekste. Mokslo taikomieji tyrimai Lietuvos kolegijose, 15, 85-93.

12. Laškovaitè, S. (2012). Fizinę negalią turinčiujų sveikatos striprinimo rekreacine veikla organizavimas. Kaunas: LSMU.

13. Rimmer, J. H., Chen, M. D., McCubbin, J. A., Drum, C. \& Peterson, J. (2010). Exercise intervention research on persons with disabilities: what we know and where we need to go. American journal of physical medicine \& rehabilitation, 89(3), 249-263.

14. Rimmer, J. H. (2005). The conspicuous absence of people with disabilities in public fitness and recreation facilities: lack of interest or lack of access? American Journal of Health Promotion, 19(5), 327-329.

15. Laškovaitè, S. (2012). Fizinę negalią turinčiụjų sveikatos striprinimo rekreacine veikla organizavimas. Kaunas: LSMU.

16. Paciorek, M. J. \& Jones, J. A. (2001). Disability sport and recreation resources. 3ed. Traverse City: Cooper Publ.

17. Rimmer, J. H., Riley, B., Wang, E., Rauworth, A., \& Jurkowski, J. (2004). Physical activity participation among persons with disabilities: barriers and facilitators. American journal of preventive medicine, 26(5), 419-425.

18. Žalkauskaité, U. (2012). Neiggaliujų identiteto daryba: teorinės prielaidos sociologijoje. Jaunųų mokslininkų darbai, 4, 113-119.

19. TFK. Tarptautinè funkcionavimo, neigalumo ir sveikatos klasifikacija. Vilnius: VU Specialiosios psichologijos laboratorija.

20. Valadkevičienè, D., Žukauskaitè, I., \& Jatužis, D. (2018). Sergančiųjų išsėtine skleroze biopsichosocialinis vertinimas, taikant Tarptautinès funkcionavimo, neiggalumo ir sveikatos klasifikacijos trumpajị kategorijų rinkinį, ir jo sąsajos su darbingumo lygiu. Neurologijos seminarai, 22(3), 201-212. 
21. Staševičienè, A., \& Fatkulina, N. (2020). Sveikatos priežiūros paslaugų prieinamumo, taikant universalaus dizaino principus, neigaliems asmenims nustatymas Lietuvoje. Kokybinio tyrimo ataskaita. Vilnius: Vilniaus universitetas Medicinos fakultetas Sveikatos mokslų institutas

22. Adomaitienè, R. (2007). Neigaliųų sociologijos pagrindai: negalių modeliai, socialinè integracija. R. Adomaitienė (Red.). Projektas „Pedagogų kvalifikacijos kėlimas darbui su įvairias negalias turinčiais mokiniais bendrojo lavinimo mokyklose“. Metodinė medžiaga, 5-28. Kaunas: Lietuvos kūno kultūros akademija.

23. Tumavičienè, Ž. (2021). Socialinių paslaugų plètotè, kaip socialinès ịtraukos prielaida, organizuojant neiggaliujų laisvalaikį. Doctoral dissertation, Vilnius: Vilniaus universitetas.

24. Mikelkevičiūtè, J. (2002). Taikomosios fizinès veiklos poveikis nežymiai protiškai atsilikusių paauglių savęs vertinimui ir kompetencijos suvokimui. Nepublikuota edukologijos daktaro disertacija, Kaunas: Lietuvos kūno kultūros akademija.

25. Ivanauskas, M. (2009). Fizinę negalią turinčių asmenų, dalyvaujančių sportinèje veikloje, gyvenimo kokybė. Šiauliai: ŠU

26. Alčiauskaitè, L. \& Šinkariova, L. (2012). Fizinę negalią turinčių asmenų saviveiksmingumo ir suvokiamos socialinès paramos sąsajos. „Visuomenès sveikata“. Views: 29-09-2021. Internet access: http://hi.simplit.lt/uploads/pdf/ visuomenes\%20sveikata/2013.3(62)/VS\%202013\%203(62)\%20ORIG\%20S\%20Judejimo\%20negalia.pdf

27. Barnes, C., \& Mercer, G. (2005). Disability, work, and welfare: Challenging the social exclusion of disabled people. Work, employment and society, 19(3), 527-545.

28. Rohe, D. E. \& Krause, J. S. (1998). Stability of interests after severe physical disability: An 11-year longitudinal study. Journal of Vocational Behavior, 52(1), 45-58. doi: 10.1006/jvbe.1996.1560

29. Larsson-Lund, M. L., Nordlund, A., Bernspång B., \& Lexell, J. (2007). Perceived participation and problems in participation are determinants of life satisfaction in people with spinal cord injury. Disability and Rehabilitation, 29(18), 1417-1422. doi: 10.1080/09638280601029068

30. Margaretten, M., Julian, L., Katz, P. \& Yelin, E. (2011). Depression in patients with rheumatoid arthritis: description, causes and mechanisms. International Journal of Clinical Rheumatology, 6(6), 617-623. doi: 10.2217/ijr.11.62

31. Tonack, M., Hitzig, S. L., Craven, B. C., Campbell, K. A., Boschen, K. A. \& McGillivray, C. F. (2008). Predicting life satisfaction after spinal cord injury in a Canadian sample. Spinal Cord, 46(5), 380-385. doi: 10.1038/sj.sc.3102088.

32. Šinkūnienè, J, R. (2005). Laisvalaikio studijos ir rekreacijos administravimas. Socialinis darbas, 4(1), $122-130$.

33. Kašètienè, N. (2009). Socialinių paslaugų poreikis kaimo seniūnijos bendruomenèje. Master's thesis, Kaunas: VDU.

34. Savickaitè, D. (2008). Sociokultūrinio darbo dilema. Socialinis darbas, 7(1), 108-117

35. Aleknaitė-Bieliauskienè R. (2003). Sociokultūrinio darbo prioritetai Lietuvoje. Lietuvos muzikos akademija kelyje į Europos aukštojo mokslo erdvę. Vilnius: LMTA

36. Šejporaitytė, D. (2011) Judejjimo negalią turinčių asmenų lyties tapatybės konstravimas. Kaunas: Vytauto Didžiojo universitetas

37. Vitkienè, E. (2008). Rekreacija. Klaipėda: Klaipėdos universiteto leidykla,

38. Radzevičienè, L., Miliūnienè, L. \& Gudonis, V. (2018). Judèjimo negalią turinčių asmenų fizinès veiklos rodikliai, susiję su jų pasitenkinimu gyvenimu ir požiūriu į savo negalią. Šiauliai: Specialusis ugdymas.

39. Beneševičiūtė I. (2015)ю Nevyriausybinių neigaliųų organizacijų veiklos plètotè socialinès integracijos kontekste. Pedagogika,115(3), 147-162.

40. Jokūbpreikšas L. \& Gudonis V. (2013) Fizinę negalią turinčių suaugusių asmenų psichologinių reakcijų ị savo negalią sąsajos su socialiniu aktyvumu. Profesinès studijos: teorija ir praktika. Views: 29-09-2021. Internet access: https:// etalpykla.lituanistikadb.lt/fedora/objects/LT-LDB-0001:J.04 2013 1395172463029/datastreams/DS.002.0.01.ARTIC/ content

41. Neigaliujų teisių konvencija. (2010). Views: 20-09-2021. Internet access: http://www.ndt.lt/ neigaliujuteisiu-konvencija/

42. Alčiauskaitè, L. \& Šinkariova, L. (2018). The Importance of Educational Level and Occupation to Adjustment to Disability Among Mobility Impaired People. Pedagogika, 129(1), 112-125.

43. Požèrienè, J., Leleika, G., \& Kailius, V. (2017). Neịgaliųjų laisvalaikio organizavimas socialines paslaugas teikiančiose institucijose. Laisvalaikio tyrimai, 1(9)

44. Lietuvos neigaliujų draugija. (2018). Neigaliųjų individualių specialiujų poreikių tenkinimo tyrimas, ịvertinant Jungtinių Tautų Neigaliụų teisių konvencijos nuostatų igyvendinimo efektyvumą. Views: 10-09-2021. Internet access: http://www.ndt.lt/wpcontent/uploads/Ne\%C4\%AFgali\%C5\%B3j\%C5\%B3-poreiki\%C5\%B3-tyrimoataskaita2018-12-07-GALUTINIS.pdf 
ШВАГЖДЕНЕ, БІРУТА - проф. др. кафедри менеджменту спорту і туризму

Литовський Університет Спорту (Каунас, Литва)

E-mail: biruta.svagzdiene@1su.lt

ORCID iD: https://orcid.org/0000-0001-6016-6019

ГРАНТС, Ю. - проф. др.

Латвійська Академія Спорту (Рига, Латвія)

E-mail: juris.grants@1spa.lv

ORCID iD: https://orcid.org/0000-0003-3116-9119

ГУТЕНЕ, ВЕРГІНІЯ - лектор факультету медицини, департамент меддопомоги

Каунаський університет прикладних наук (Каунас, Литва)

E-mail: virginija.gutiene@go.kauko.lt

ORCID iD: https://orcid.org/0000-0001-9402-5767

\title{
УПРАВЛІННЯ РЕКРЕАЦІЙНОЇ ДІЯЛЬНІСТЮ ЛЮДЕЙ 3 ОБМЕЖЕНИМИ ФІЗИЧНИМИ МОЖЛИВОСТЯМИ
}

\begin{abstract}
Анотація
Баланс між активністю та відпочинком необхідний для здоров'я людини. Відпочинок є особливо актуальним для людей з обмеженими фізичними можливостями, які хочуть відновити свої фізичні, духовні та емоційні сили і при цьому з користю провести вільний час. Відпочинок покращує не лише обмежені фізичні можливості, моторику, а й самооцінку люждей, здатність спілкуватися та співпрацювати, сприяє мотивації до участі у різних заняттях. Люди з обмеженими фізичними можливостями, як і раніше, стикаються з нестачею інформації про розважальні заходи та їх доступність, що може бути пов'язане з відсутністю мотивації до занять фізичними вправами та низьким рівнем фізичної активності. Актуальність дослідження також визначається відсутністю досліджень, пов'язаних з організацією відпочинку та дозвілля інвалідів у Литві. Тим, хто сьогодні хоче вирішити проблеми якості дозвілля у соціальній системі, особливо не вистачає кваліфікованих знань та досліджень. Очікується, що це дослідження хоча б частково покаже, чи є відпочинок та дозвілля інвалідів у Литві досить добре організованим та доступним для людей з обмеженими фізичними можливостями. Ситуація у Литві з погляду відпочинку для людей з обмеженими фізичними можливостями вичена недостатньо, тому ця робота допоможе оцінити поточну ситуацію та дати рекомендації щодо подальшого розвитку відпочинку для людей з обмеженими фізичними можливостями. Завдання: визначити доступність та організацію оздоровлення в оздоровчих заходах для осіб 3 обмеженими фізичними можливостями; виявити можливий вплив економіко-фінансових, інформаційних, фізичних та психосоціальних факторів середовища на участь людей з обмеженими фізичними можливостями в рекреаційній діяльності з метою зміцнення здоров'я; обговорити потреби у дозвіллі та можливості задоволення осіб з обмеженими фізичними можливостями. Методи: аналіз, систематизація та інтерпретація наукової літератури.

Ключові слова: управління відпочинком, здоров'я, людина з обмеженими фізичними можливостями, рекреаційна діяльність, дозвілля.
\end{abstract}

ШВАГЖДЕНЕ, БИРУТА - проф. др. кафедры менеджмента спорта и туризма Литовский Университет Спорта (Каунас, Литва)

E-mail: biruta.svagzdiene@1su.1t

ORCID iD: https://orcid.org/0000-0001-6016-6019

ГРАНТС, Ю. - проф. др.

Латвийская Академия Спорта (Рига, Латвия)

e-mail: juris.grants@1spa.lv

ORCID iD: https://orcid.org/0000-0003-3116-9119

ГУТЕНЕ, ВИРГИНИЯ - лектор факультета Медицины, департамент медпомощи

Каунасский университет прикладных наук (Каунас, Литва)

E-mail: virginija.gutiene@go.kauko.lt

ORCID iD: https://orcid.org/0000-0001-9402-5767

Manageme of recreational activities for persons with physical disabilities 


\title{
УПРАВЛЕНИЕ РЕКРЕАЦИОННОЙ ДЕЯТЕЛЬНОСТЬЮ ЛЮДЕЙ С ОГРАНИЧЕННЫМИ ФИЗИЧЕСКИМИ ВОЗМОЖНОСТЯМИ
}

\begin{abstract}
Аннотация
Баланс между активностью и отдыхом необходим для здоровья человека. Отдых особенно актуален для людей с ограниченными возможностями, которые хотят восстановить свои физические, духовные и эмоциональные силы и при этом с пользой провести свободное время. Отдых улучшает не только физические возможности, моторику, но и самооценку людей с ограниченными возможностями, способность общаться и сотрудничать, что способствует мотивации к участию в различных занятиях. Люди с ограниченными возможностями по-прежнему сталкиваются с недостатком информации о развлекательных мероприятиях и их доступности, что может быть связано с отсутствием мотивации к занятиям физическими упражнениями и низким уровнем физической активности. Актуальность исследования также определяется отсутствием исследований, связанных с организацией отдыха и досуга инвалидов в Литве. Тем, кто сегодня хочет решить проблемы качества досуга в социальной системе, особенно не хватает квалифицированных знаний и исследований. Ожидается, что это исследование хотя бы частично покажет, является ли отдых и досуг людей с ограниченными возможностями в Литве достаточно хорошо организованным и доступным для людей с ограниченными физическими возможностями. Ситуация в Литве с точки зрения отдыха для людей с ограниченными возможностями изучена недостаточно, поэтому эта работа поможет оценить текущую ситуацию и дать рекомендации по дальнейшему развитию отдыха для инвалидов. Задачи: определить доступность и организацию оздоровления в оздоровительных мероприятиях для лиц с ограниченными физическими возможностями; выявить возможное влияние экономико-финансовых, информационных, физических и психосоциальных факторов среды на участие инвалидов в рекреационной деятельности в целях укрепления здоровья; обсудить потребности в досуге и возможности удовлетворения лиц с ограниченными физическими возможностями. Методы: анализ, систематизация и интерпретация научной литературы.

Ключевые слова: управление отдыхом, здоровье, человек с ограниченными физическими возможностями, рекреационная деятельность, досуг
\end{abstract}

(C) The Author(s) 2021

Received date 31.09.2021

This is an open access article under

Accepted date 15.10.2021

the Creative Commons CC BY license

Published date 15.11.2021

How to cite: Svagzdiene, Biruta, Grants, Juris \& Gutiene, Virginija. Manageme of recreational activities for persons with physical disabilities. HUMANITIES STUDIES : Collection of Scientific Papers / ed. V. Voronkova. Zaporozhzhia : Publishing house "Helvetica", 2021. 9(86). P. 80-90.

doi: https://doi.org/10.26661/hst-2021-9-86-09 